\title{
DEMISE OF THE MIDDLE PALEOZOIC CRINOID FAUNA: GRADUAL OR MASS EXTINCTION?
}

\author{
KAMMER*, Thomas W., Department of Geology and Geography, West Virginia \\ University, Morgantown, WV 26506, U.S.A.; AUSICH, William I., Department of \\ Geological Sciences, The Ohio State University, Columbus, OH 43210, U.S.A.
}

There are essentially three major crinoid faunas of the Paleozoic: 1 ) the lower Paleozoic (Ordovician) fauna dominate by disparids and diplobathrid camerates; 2 ) the middle Paleozoic (Silurian-middle Mississippian) fauna dominated by monobathrid camerates, cladids, and flexibles; and 3) the upper Paleozoic (middle MississippianPermian) fauna dominated by cladids. Change from the middle Paleozoic fauna to the late Paleozoic fauna, at or near the Osagean-Meramecian boundary, was characterized by Laudon (1948) as "one of the most remarkable faunal breaks in the entire Paleozoic era". The monobathrids that had reached their zenith in the Osagean (Tournaisian-Visean) became a very minor component of late Paleozoic faunas. Conventional thinking has implied that a mass extinction of crinoids occurred at the Osagean-Meramecian boundary.

We have biostratigraphically subdivided the late Osagean and early Meramecian into four zones (times A-D, oldest to youngest, all within the Gnathodus texanus zone) in order to study the origination and extinction of all crinoid species during the changeover from the middle to upper Paleozoic faunas. Rather than a mass extinction, a monotonic turnover of species fits a pattern of gradual extinction as extinctions outpaced originations. Data are based on 216 species (taxonomically updated) from 69 localities and are as follows:

\begin{tabular}{|c|c|}
\hline Species originations & Species extinctions \\
\hline Time D: $32 / 81=40 \%$ & Time D: $71 / 81=88 \%$ \\
\hline Time C: $27 / 94 \stackrel{\text { Osagean-N }}{=}=29 \%$ & ooundary \\
\hline $\begin{array}{l}\text { Time C: } 27 / 94=29 \% \\
\text { Time B: } 112 / 145=77 \%\end{array}$ & $\begin{array}{l}\text { Time C: } 44 / 94=47 \% \\
\text { Time B: } 76 / 145=52 \%\end{array}$ \\
\hline Time A: $33 / 47=70 \%$ & Time A: $18 / 47=38$ \\
\hline
\end{tabular}

The pattern of originations and extinctions for monobathrids is very similar to the pattern for all crinoid species.

The above data have maximum diversity during Time B of the late Osagean followed by declining diversity in times $\mathrm{C}$ and $\mathrm{D}$ into the early Meramecian. Late Meramecian crinoid faunas (after time D) were less diverse with a maximum of about 45 species. The gradual decline of crinoids across the Osagean-Meramecian boundary cannot be explained as sampling bias (Signor-Lipps effect), because ranges of crinoids thought to be extinct at the boundary are extended into the early Meramecian as well as disappearing at various times prior to the boundary.

The decline in diversity and the monotonic turnover of species are hypothesized to be the result of habitat reduction as the Eastern Interior Basin of North America was gradually infilled with clastic sediments at the end of the Acadian Orogeny. Most notable in this regard was the smothering of the Keokuk Limestone carbonate bank. Changes in sea level also contributed to habitat reduction. Lowering of sea level at the end of the Osagean caused restriction of open marine environments. A transgression in the early Meramecian was followed by shoaling and restriction during deposition of the late Meramecian Salem and St. Louis limestones. 